\author{
Sylwia StryjKowska
}

\title{
The International Legal Issue of Attribution of Conduct to a State - The Case Law of the International Courts and Tribunals
}

\section{Introduction}

Draft Articles on Responsibility of States for Internationally Wrongful Acts (henceforth referred to as the ILC Articles) were adopted by the International Law Commission on 10 August 2001. Four months later, on 12 December 2001, the General Assembly of the United Nations commended the work to the attention of governments without prejudice to the question of their future adoption or other appropriate action. ${ }^{1}$ Despite the fact that almost two decades have passed, still no decision has been made as to the final form of the document. The need for regulation was emphasised right from the beginning of the existence of the ILC - in 1949 the topic "State responsibility" was selected as one of the fourteen topics suitable for codification. It was recognized as of major importance in the relations of States; therefore it took more than forty years to conclude the work with the draft articles and produce a detailed commentary on the subject. Throughout that time basic concepts of State responsibility, such as attribution, breach, excuses and consequences were examined and set out in 59 Articles. The second Special Reporter of the ILC - Robert Ago established the basic structure of the document, which originates from the division of norms into primary and secondary. The ILC Articles aim to present the general conditions for State responsibility - the emphasis is on the secondary rules of State responsibility, without the ambition to define the content of the primary obligations of States. ${ }^{2}$

In the final form, the ILC Articles are divided into four parts and subdivided into chapters. Part One, entitled "The internationally wrongful act of a State”, recognizes the requirements for the international responsibility of a State to arise. Article 2 may therefore be treated as its core provision, since it states that in order to invoke the interna-

1 General Assembly Resolution, 28 January 2002, UN Doc. A/RES/56/83.

2 Draft Articles on Responsibility of States for Internationally Wrongful Acts, with commentaries, Yearbook of the International Law Commission, 2001, vol. II, Part Two, UN Doc. A/56/83 (2001), General commentary, §§1. 
tional responsibility of a State, it is essential to establish both that a conduct in question is attributable to a State and that it constitutes a breach of its international obligation. Commentary to the ILC Draft describes the process of attribution as a normative operation, which must be distinguished from the second constituent element of the international responsibility of a State, i.e. characterization of a State's act as internationally wrongful. ${ }^{3}$ Therefore, both "subjective" and "objective" conditions must be met, although the ILC Articles themselves avoid such terminology. Apart from formulating principles, which enable the characterization of an act of a State as internationally wrongful, one of the main purposes of the document was to determine under what circumstances given conduct can be attributed to a State as a subject of international law. That important topic is dealt with in Articles 4-11 - the second chapter of the ILC Articles broadens the subject of attributing conduct to a State. A general rule of attribution is expressed in Article $4^{4}$, which states that only the conduct of the organs of government is attributable to a State. States as peculiar juridical abstractions ${ }^{5}$ act only through their organs, instrumentalities and officials which constitute part of its organization. Of course it is the role of internal law to decide on the structure of a State - appointment of its organs and determining the functions assigned to them. On the other hand, the task of international law is to prevent States' attempts to avoid responsibility by recalling their internal structure - therefore national law is not the only tool used in the process of classification ${ }^{6}$. The basic danger of such an approach would be the possibility of carrying out unlawful conduct through allegedly non-state actors without incurring responsibility. Even if internal law denies the existence of a formal link between an individual and a State, that person can still be equated with de facto State organ if there is a relationship of 'complete dependence' on the State. ${ }^{7}$ Legal status established under internal law is therefore not the only factor determining the potential responsibility of a State.

3 Commentary to the ILC Articles, p. 39, § 4.

4 Article 4 of the ILC Articles: "1. The conduct of any State organ shall be considered an act of that State under international law, whether the organ exercises legislative, executive, judicial or any other functions, whatever position it holds in the organization of the State, and whatever its character as an organ of the central Government or of a territorial unit of the State. 2. An organ includes any person or entity which has that status in accordance with the internal law of the State".

5 The term used by J. Crawford and S. Olleson in The Nature and Forms of International Responsibility, in: International Law, ed. M. D. Evans, Oxford 2003, p. 454.

6 "(...) international law does not permit a State to escape its international responsibilities by a mere process of internal subdivision. The State as a subject of international law is held responsible for the conduct of all the organs, instrumentalities and officials which form part of its organization and act in that capacity, whether or not they have separate legal personality under its internal law". See Commentary to the ILC Articles, p. 39, §7.

7 In Case Concerning Application of the Convention on the Prevention and Punishment of the Crime of Genocide the International Court of Justice held that: "(...) persons, groups of persons or entities may, for purposes of international responsibility, be equated with State organs even if that status does not follow from internal law, provided that in fact the persons, groups or entities 
Apart from the general rule, the second chapter of the ILC Articles provides for more complex scenarios, where a State is responsible for the conduct of private persons. Those specific circumstances involve:

- the conduct of a person or entity, which is not an organ of the State but is empowered under national law to exercise delegated governmental functions (Article 5);

- the conduct of State organs placed at a disposal of another State (Article 6);

- conduct in excess of authority (Article 7);

- conduct directed or controlled by a State (Article 8);

- conduct carried out in the absence or default of the official authorities (Article 9);

- the conduct of an insurrectional or other movement, which succeeds in becoming the new Government of the State (Article 10);

- conduct acknowledged and adopted by a State as its own (Article 11).

\section{The Topic of Attribution in the Case Law}

Long before the final adoption of the ILC Articles, the International Court of Justice (henceforth referred to as the ICJ) had dealt with the issue of attribution. In the United States Diplomatic and Consular Staff in Tehran case ${ }^{8}$ it observed that in order to prove the responsibility of the Islamic Republic of Iran it is crucial to "determine how far, legally, the acts in question may be regarded as imputable to the Iranian State." ${ }^{9}$ Therefore, the Court had to examine the relationship between the Iranian students who had attacked the United States embassy and the government of Iran. In this regard it examined statements made by various governmental authorities in Iran and held:

the policy thus announced by the Ayatollah Khomeini, of maintaining the occupation of the Embassy and the detention of its inmates as hostages for the purpose of exerting pressure on the United States Government was complied with by other Iranian authorities and endorsed by them repeatedly in statements made in various

act in "complete dependence" on the State, of which they are ultimately merely the instrument. In such a case, it is appropriate to look beyond legal status alone, in order to grasp the reality of the relationship between the person taking action, and the State to which he is so closely attached as to appear to be nothing more than its agent: any other solution would allow States to escape their international responsibility by choosing to act through persons or entities whose supposed independence would be purely fictitious". ICJ, Case Concerning Application of the Convention on the Prevention and Punishment of the Crime of Genocide (Bosnia and Hercegovina v. Serbia and Montenegro), Judgement of 26 February 2007, § 392.

8 ICJ, Case Concerning United States Diplomatic and Consular Staff in Teheran (United States of America v. Iran), Judgement of 24 May 1980.

9 Ibidem, $§ 56$. 
contexts. The result of that policy was fundamentally to transform the legal nature of the situation created by the occupation of the Embassy and the detention of its diplomatic and consular staff as hostages. The approval given to these facts by the Ayatollah Khomeini and other organs of the Iranian State, and the decision to perpetuate them, translated continuing occupation of the Embassy and detention of the hostages into acts of that State. The militants, authors of the invasion and jailers of the hostages, had now become agents of the Iranian State, for whose acts the State itself was internationally responsible. ${ }^{10}$

By this means the Court acknowledged that an act which constitutes a breach of international law should be attributed to the State, if it was publicly approved ex post facto. Under such circumstances, persons directly responsible for such conduct should be equated with de facto agents of the State - the scenario currently provided for in Article 11 of the ILC Articles. ${ }^{11}$ This deals with cases in which conduct was not attributable to a State at the time of the commission, however an unequivocal and unqualified acknowledgement and adoption may be granted a retroactive effect, making a State responsible $a b$ initio. ${ }^{12}$ In the words of the commentary, such a solution "avoids gaps in the extent of responsibility for what is, in effect, the same continuing act". ${ }^{13}$ As for the requirement of subsequent acknowledgement or adoption, it is worth pointing out that in order to transform the legal nature of private conduct, it must extend mere support or endorsement. ${ }^{14}$ In other words, Article 11 provides for a situation where the State identifies the conduct and translates it into its own acts.

The case at hand can, moreover, be seen as a significant contribution to the discussion on accountability for prevention, since the Court pointed out that Iran was responsible for its failure to prevent crimes against internationally protected persons. ${ }^{15} \mathrm{Such}$ a mechanism may be used when the rules of attribution do not allow a State to be held accountable for the unlawful acts of private actors. Under such circumstances a State

10 Ibidem, § 74.

11 Article 11 of the ILC Articles: "Conduct which is not attributable to a State under the preceding articles shall nevertheless be considered an act of that State under international law if and to the extent that the State acknowledges and adopts the conduct in question as its own".

12 Commentary to Article $11, \S 4$.

13 Ibidem.

14 Commentary to Article $11, \S 6$.

15 The responsibility of Iran for failure to take any steps to prevent the attacks was distinguished from accountability for private conduct: “The Iranian authorities' decision to continue the subjection of the premises of the United States Embassy to occupation by militants and of the Embassy staff to detention as hostages, clearly gave rise to repeated and multiple breaches of the applicable provisions of the Vienna Conventions even more serious than those which arose from their failure to take any steps to prevent the attacks on the inviolability of these premises and staff". Case Concerning United States Diplomatic and Consular Staff in Teheran, § 76. 
may still be held responsible for its own conduct which consists in lack of prevention, since as M. Dixon puts it: "irrespective of the question of attributability, a State may incur primary responsibility because of a breach of some other international obligation, even though this obligation arose of the situation created by a non-attributable act". ${ }^{16}$ In other words, instead of being responsible for purely private conduct, a State is held accountable for a separate delict, which amounts to failure to comply with its obligation, whether positive or negative. ${ }^{17}$ Such an approach is reflected in the 'separate delict theory', expressed in the fourth report on State responsibility submitted by the Special Rapporteur R. Ago in 1972. According to the document, in the case of failure to fulfil an obligation to prevent unlawful conduct of private actors, the state is "responsible for having violated not the international obligation with which the individual's action might be in contradiction, but the general or specific obligation imposing on its organs a duty to provide protection" ${ }^{18}$

The same stance was taken in the case Concerning Application of the Convention on the Prevention and Punishment of the Crime of Genocide. Admittedly, the ICJ held that the conduct of VRS and paramilitary groups was not attributable to Serbia and Montenegro, since they did not constitute organs of the Respondent (whether de jure or de facto). However, the Court held Serbia and Montenegro responsible for infringement of its obligation to prevent the genocide, since it did nothing to prevent the atrocities committed by the Bosnian Serbs in Srebrnica. That kind of responsibility was expressly distinguished from accountability for de jure or de facto state organs ${ }^{19}$.

Another facet of the issue of attributing private conduct to a State has also been the subject of consideration of arbitral tribunals, including the Iran-United States Claims Tribunal. In the Kenneth P. Yeager case ${ }^{20}$ it had to assess whether the conduct of the Iranian revolutionary "Komitehs" or "Guards" could be attributed to Iran. Admittedly, international law did not recognize them as part of the official authorities, but the actual

16 M. Dixon, Textbook on International Law, Oxford 2007, p. 252.

17 Vid. E. Nielsen, State Responsibility for Terrorist Groups, in: "U. C. Davis Journal of International Law and Policy" 2010, Vol.17, p. 167.

18 The fourth report on State responsibility, by Roberto Ago, Special Rapporteur - The internationally wrongful act of the State, source of international responsibility (continued), Yearbook of the International Law Commission, 1972, Vol. II, UN Doc. A/CN.4/264, § 140.

19 E. Nielsen, op. cit., p. 167.

20 Kenneth P. Yeager v. Islamic Republic of Iran, Iran-U.S. Claims Tribunal Reports, 1987, vol. IV, p. 92.It was one of the cases concerning unlawful expulsion of a United States national from the territory of Iran during the Iranian revolution in 1979. For further comment on the case vid. M. Leigh, Yeager v. Islamic Republic of Iran. AWD 324-10199-1; AND Rankin v. Islamic Republic of Iran. AWD 326-10913-2, "The American Journal of International Law"1988, Vol. 82, no. 2, pp. 353-362; M. Haddadi, H. Khosroshahi, Disguised Expulsion from Iran-United States Tribunal to the International Law Commission's Draft on the Expulsion of Aliens, "International Journal of Academic Research in Public Policy and Governance” 2015, Vol. 2, no. 1, p. 18. 
exercise of governmental authority in the absence of the previous State apparatus and tolerance to the exercise of public functions by revolutionary guards gave rise to the claim that Iran was responsible for their unlawful acts. Therefore, once again, despite the lack of an official relationship between the perpetrators of the act and the State, responsibility of the latter was established that time by reference to the then Article 8(b) of the 1975 ILC Articles, which expressed the principle that a State is responsible for the acts of private persons if they were "in fact exercising elements of governmental authority in the absence of the official authorities and in circumstances which justified the exercise of those elements of authority" ${ }^{21}$ - the situation currently dealt with in Article 9. ${ }^{22}$

After the final adoption of the ILC Articles, they have been applied on numerous occasions by international courts and tribunals. What is more, the jurisprudence acknowledged the fact that the provisions of the document constituted in fact customary international law. The International Court of Justice, which made reference to provisions of the Articles on a number of occasions, has adopted that approach inter alia on the occasion of its aforementioned considerations of whether the actions of VRS and paramilitary groups in relation to the genocide in Srebrnica were attributable to Serbia and Montenegro. In the course of its examination on the relationship between the respondent and perpetrators of genocide, operating on the territory of Bosnia and Herzegovina, the Court observed that "on this subject the applicable rule, which is one of customary law of international responsibility, is laid down in Article 8 of the ILC Articles on State Responsibility". ${ }^{23}$

The principles connected with the process of attribution expressed in the ILC Articles have not only been reaffirmed on numerous occasions, but have also become the source of controversies stemming from different understandings of its provisions. For instance, references to the aforementioned Article 8 have led to disputes on the interpretation of the notion "control". Under its provisions " $[t]$ he conduct of a person or group of persons shall be considered an act of a State under international law if the person or group of persons is in fact acting on the instructions of, or under the direction or control of, that State in carrying out the conduct". Commentary to Article 8 formulated in this regard the requirement of "a real link between the person or group performing the act and the State machinery" 24 but at the same time acknowledged that the issue of determining

21 Yearbook of the International Law Commission 1975, UN Doc. A/CN.4/SER.A/1975/Add. 1.

22 Article 9 of the ILC Articles: "The conduct of a person or group of persons shall be considered an act of a State under international law if the person or group of persons is in fact exercising elements of the governmental authority in the absence or default of the official authorities and in circumstances such as to call for the exercise of those elements of authority".

23 Case Concerning Application of the Convention on the Prevention and Punishment of the Crime of Genocide, § 398.

24 Commentary to Article 8, $§ 1$. 
whether the unlawful conduct was carried out under the direction or control of a State is a complex one.

The verdict which initiated discussion on that issue and in fact gave rise to Article 8 provisions was delivered by the ICJ in 1986 in the Military and Paramilitary Activities in and against Nicaragua case. In this case the Court had to assess whether the conduct of the contras was attributable to the United States. To this end it analysed the degree of control that United States exercised over these rebel groups operating on a territory of Nicaragua. Having examined the material available it found:

(...) despite the heavy subsidies and other support provided to them by the United States, there is no clear evidence of the United States having actually exercised such a degree of control in all fields as to justify treating the contras as acting on its behalf. (...) United States participation, even if preponderant or decisive, in the financing, organizing, training, supplying and equipping of the contras, the selection of its military or paramilitary targets, and the planning of the whole of its operation, is still insufficient in itself, on the basis of the evidence in the possession of the Court, for the purpose of attributing to the United States the acts committed by the contras in the course of their military or paramilitary operations in Nicaragua. All the forms of United States participation mentioned above, and even the general control by the respondent State over a force with a high degree of dependency on it, would not in themselves mean, without further evidence, that the United States directed or enforced the perpetration of the acts contrary to human rights and humanitarian law alleged by the applicant State. Such acts could well be committed by members of the contras without the control of the United States. For this conduct to give rise to legal responsibility of the United States, it would in principle have to be proved that that State had effective control of the military or paramilitary operations in the course of which the alleged violations were committed. ${ }^{25}$

However, the problem of attribution has not always been resolved on the basis of the "effective control" test. Further judgements, described below, prove that different kinds of tests have been applied to establish State responsibility. In particular, another famous verdict - always recalled in the context of that issue - formulated different standards in

25 The ICJ, Case Concerning Military and Paramilitary Activities In and Against Nicaragua (Nicaragua v. United States of America), Judgement of 27 June 1986, paras. 109, 115. By holding in the Commentary to the ILC Articles that “(...) conduct will be attributable to the State only if it directed or controlled the specific operation and the conduct complained of was an integral part of that operation. The principle does not extend to conduct which was only incidentally or peripherally associated with an operation and which escaped from the State's direction or control" the ILC implicitly endorsed the position adopted by the ICJ in the Military and Paramilitary Activities in and against Nicaragua case and approved of the principle of effectiveness. 
that regard. In the Tadic case the Appeals Chamber of the International Criminal Tribunal for the former Yugoslavia (henceforth referred to as ICTY) examined the factual relationship between the Bosnian Serb Army and the Army of the Federal Republic of Yugoslavia (FRY) and based its verdict on the assumption that varying degrees of sufficient control should be established in each case. ${ }^{26}$ In that context, the Tribunal paid attention to the possible dangers of rigid interpretation of norms reflecting the principles of attribution, emphasising that it may lead to attempts to avoid responsibility by invoking individuals' perpetration of the unlawful conduct. ${ }^{27}$ In the light of the above, the Tribunal reached the decision that "[i]n the case at issue, given that the Bosnian Serb armed forces constituted a military organization, the control of the FRY authorities over these armed forces required by international law for considering the armed conflict to be international was overall control going beyond the mere financing and equipping of such forces and involving also participation in the planning and supervision of military operations. By contrast, international rules do not require that such control should extend to the issuance of specific orders or instructions relating to single military actions, whether or not such actions were contrary to international humanitarian law". ${ }^{28}$

The same problems were considered by the ICJ after the final adoption of the ILC Articles. In the case concerning Armed Activities on the Republic of the Congo $0^{29}$ the Court had to assess whether the conduct of paramilitary groups (MLC - Movement for the Liberation of Congo) carried out on a territory of the DRC was attributable to Uganda. Although it did not clearly express its opinion on a preferred "control test", it seems that by referral to the Military and Paramilitary Activities in and against Nicaragua case it implicitly approved

26 "The principles of international law concerning the attribution to States of acts performed by private individuals are not based on rigid and uniform criteria. (...) The degree of control may (...) vary according to the factual circumstances of each case. The Appeals Chamber fails to vid. why in each and every circumstance international law should require a high threshold for the test of control. Rather, various situations may be distinguished". ICTY, Prosecutor v. Duško Tadic, Appeals Chamber Judgement of 15 July 1999, Case no. IT-94-1-A, § 117.

27 "Under this Article [Article 8], if it is proved that individuals who are not regarded as organs of a State by its legislation nevertheless do in fact act on behalf of that State, their acts are attributable to the State. The rationale behind this rule is to prevent States from escaping international responsibility by having private individuals carry out tasks that may not or should not be performed by State officials, or by claiming that individuals actually participating in governmental authority are not classified as State organs under national legislation and therefore do not engage State responsibility. In other words, States are not allowed on the one hand to act de facto through individuals and on the other to disassociate themselves from such conduct when these individuals breach international law. The requirement of international law for the attribution to States of acts performed by private individuals is that the State exercis.es control over the individuals". Ibidem.

28 Ibidem, § 145.

29 ICJ, Case Concerning Armed Activities on the Republic of the Congo (Democratic Republic of the Congo v. Uganda), Judgement of 19 December 2005. 
of the "effective control" test. In the course of its considerations the ICJ rejected three possible scenarios on which the responsibility of Uganda could have been established: first, that the MLC constituted an organ of Uganda (Article 4), second implying that it was an entity exercising elements of governmental authority on its behalf (Article 5), and third - based on the lack of probative evidence - that it acted on the instructions of, or under the direction or control of Uganda (Article 8). ${ }^{30}$ As far as the last circumstance is concerned the Court held that " $(. .$.$) no issue arises in the present case as to whether the requisite tests are met for suf-$ ficiency of control of paramilitaries". ${ }^{31}$ Therefore, the remaining margin of autonomy of the MLC prevented the Court from qualifying the unlawful conduct as attributable to Uganda.

By contrast, in the aforementioned case Concerning Application of the Convention on the Prevention and Punishment of the Crime of Genocide the ICJ was highly critical of the interpretation advocated by the majority in the Tadic case and resolved the dispute between two opposing approaches in favour of an "effective control" test, emphasising that

"(...) the overall control test has the major drawback of broadening the scope of State responsibility well beyond the fundamental principle governing the law of international responsibility: a State is responsible only for its own conduct, that is to say the conduct of persons acting, on whatever basis, on its behalf. That is true of acts carried out by its official organs, and also by persons or entities which are not formally recognized as official organs under internal law but which must nevertheless be equated with State organs because they are in a relationship of complete dependence on the State. Apart from these cases, a State's responsibility can be incurred for acts committed by persons or groups of persons - neither State organs nor to be equated with such organs - only if, assuming those acts to be internationally wrongful, they are attributable to it under the rule of customary international law reflected in Article 8 cited above. This is so where an organ of the State gave the instructions or provided the direction pursuant to which the perpetrators of the wrongful act acted or where it exercised effective control over the action during which the wrong was committed. In this regard the overall control test is unsuitable, for it stretches too far, almost to breaking point, the connection which must exist between the conduct of a State's organs and its international responsibility". ${ }^{22}$

30 "The Court concludes that there is no credible evidence to suggest that Uganda created the MLC. Uganda has acknowledged giving training and military support and there is evidence to that effect. The Court has not received probative evidence that Uganda controlled, or could control, the manner in which Mr. Bemba put such assistance to use. In the view of the Court, the conduct of the MLC was not that of "an organ" of Uganda, nor that of an entity exercising elements of governmental authority on its behalf. The Court has considered whether the MLC's conduct was "on the instructions of, or under the direction or control of" Uganda and finds that there is no probative evidence by reference to which it has been persuaded that this was the case." Ibidem $\S 160$.

31 Ibidem, § 160.

32 Case Concerning Application of the Convention on the Prevention and Punishment of the Crime of Genocide, § 406. 
Moreover, it disputed the ICTY's argument that control does not have to extend to the issuance of specific orders or instructions relating to single military actions and held that it is required "that the State's instructions were given, in respect of each operation in which the alleged violations occurred, not generally in respect of the overall actions taken by the persons or groups of persons having committed the violations". ${ }^{33}$

It is worth mentioning that the interpretation of the majority of the ICJ encountered opposition from Vice President Al-Khasawneh, who advocated for variations in the rules of attribution in accordance with the stance taken by the ICTY. In a dissenting opinion appended to the judgement of the Court he observed that a required level of control should vary according to the circumstances of each case. ${ }^{34}$ To support his claim he pointed out that the subject of varying degrees of sufficient control was debated during the sessions of the ILC, when some of its members drew attention to possible scenarios in which States admittedly did not give any formal and explicit instructions or did not exercise direct control, but at the same time facilitated or encouraged individuals or groups to commit unlawful conduct. ${ }^{35}$ In that context, the Vice President again brought up arguments put forward in the Tadic case and continued that "[ $\mathrm{t}]$ he inherent danger in such an approach [ICJ's approach in case Concerning Application of the Convention...] is that it gives States the opportunity to carry out criminal policies through non-state actors or surrogates without incurring direct responsibility therefore" ${ }^{36}$

Personally, I adhere to the ICJ's view that "[t] he rules of attributing alleged internationally wrongful conduct to a State do not vary with the nature of the wrongful act in question in the absence of a clearly expressed lex specialis". ${ }^{37}$ This means that the general rule of attribution expressed in Article 8 must be identical, despite the peculiar circumstances of each case. ${ }^{38}$ If not determined by the factual circumstances, the requisite degree of control should therefore be regarded as an invariable standard. However, the requisite level of State involvement in private conduct may vary according to the legal nature of the case. ${ }^{39}$

33 Ibidem, $§ 400$.

34 “(...) with great respect to the majority, a strong case can be made for the proposition that the test of control is a variable one".Ibidem, Dissenting Opinion of Vice President Al-Khasawneh, $\S 37$.

35 Report of the International Law Commission on the work of its fiftieth session, 20 April-12 June and 27 July-14 August 1998, Official Records of the General Assembly, Fifty-third session, Supplement no. 10, UN Doc. A/53/10, § 394-396.

36 Case Concerning Application of the Convention on the Prevention and Punishment of the Crime of Genocide, Dissenting Opinion of Vice President Al-Khasawneh, § 39.

37 Ibidem, § 401.

38 See also S. Wittich, The International Law Commission's Articles on the Responsibility of States for Internationally Wrongful Acts Adopted on Second Reading, "Leiden Journal of International Law" 2002, Vol. 15, Issue 4, p. 894.

39 Having concluded that the factual and legal situation of both cases was different, the Court also acknowledged that it is not required to resolve the two issues of different nature on the 
It should be noted that such the stark contrast of views on the required level of control between the ICJ and the ICTY may be attributable to differences that occur on a jurisdictional level. Issues covered by the mandate of the ICJ concern State responsibility, while ICTY's jurisdiction is criminal and extends only over persons. ${ }^{40}$ Therefore, the issue of control was examined in different contexts - the ICJ decided on attribution requirements, whereas the ICTY's considerations aimed at establishing the character of the conflict in order to find applicable rules of international humanitarian law. In this regard, proving the relationship between Bosnian Serbs and the FRY was necessary to determine whether it was of an international character. That is why the commentary to the ILC Articles points out that not only the factual situation, but also the legal issues of both cases were different. ${ }^{41}$

\section{Conclusion}

The ILC Articles determine and describe two constituent elements of international responsibility - conduct needs to be attributable to a State and inconsistent with its international obligations. This article has surveyed, albeit briefly, the main principles of attribution which were affirmed in international judicial decisions. Under the general rule of attribution, States incur responsibility only for the conduct of its organs. However, under specific circumstances, the process of attribution may also extend to acts of persons authorized, directed or controlled, as well as to private conduct publicly approved. Besides this, in cases when it is impossible to hold a State responsible for private conduct under the principles of attribution, it may still incur responsibility for its failure to prevent the unlawful act in conformity with a 'separate delict theory'. Analysis of international jurisprudence leaves no doubt that the Draft Articles on the Responsibility of States for Internationally Wrongful Acts constitute a primary point of reference in relation to those issues and that the underlying principles of the document have been reaffirmed many times since their final adoption.

basis of the same control test: “(...) the degree and nature of a State's involvement in an armed conflict on another State's territory which is required for the conflict to be characterized as international, can very well, and without logical inconsistency, differ from the degree and nature of involvement required to give rise to that State's responsibility for a specific act committed in the course of the conflict". Case Concerning Application of the Convention on the Prevention and Punishment of the Crime of Genocide, $\$ 405$.

40 See the stance taken by the ICJ: "First, the Court observes that the ICTY was not called upon in the Tadić case, nor is it in general called upon, to rule on questions of State responsibility, since its jurisdiction is criminal and extends over persons only. Thus, in that Judgment the Tribunal addressed an issue which was not indispensable for the exercise of its jurisdiction". Ibidem, § 403.

41 Commentary to Article $8, \S 5$. 
154 | Adam Mickiewicz University Law Review

\section{Literature}

Crawford J., Olleson S., The Nature and Forms of International Responsibility, International Law, ed. M. D. Evans, Oxford 2003.

Dixon M., Textbook on International Law, Oxford 2007.

Haddadi M., Khosroshahi H., Disguised Expulsion from Iran-United States Tribunal to the International Law Commission's Draft on the Expulsion of Aliens, "International Journal of Academic Research in Public Policy and Governance” 2015, vol. 2, no. 1.

Leigh M., Yeager v. Islamic Republic of Iran. AWD 324-10199-1; AND Rankin v. Islamic Republic of Iran. AWD 326-10913-2, "The American Journal of International Law" 1988, Vol. 82, no. 2.

Nielsen E., State Responsibility for Terrorist Groups, "U. C. Davis Journal of International Law and Policy" 2010, vol. 17.

Wittich S., The International Law Commission's Articles on the Responsibility of States for Internationally Wrongful Acts Adopted on Second Reading, "Leiden Journal of International Law” 2002, vol. 15, issue 4.

Draft Articles on Responsibility of States for Internationally Wrongful Acts, with commentaries, Yearbook of the International Law Commission, 2001, vol. II, Part Two, UN Doc. A/56/83 (2001).

Fourth report on State responsibility, by Roberto Ago, Special Rapporteur - The internationally wrongful act of the State, source of international responsibility (continued), Yearbook of the International Law Commission, 1972, vol. II, UN Doc. A/CN.4/264. General Assembly Resolution, 28 January 2002, UN Doc. A/RES/56/83.

Report of the International Law Commission on the work of its fiftieth session, 20 April - 12 June and 27 July - 14 August 1998, Official Records of the General Assembly, Fifty-third session, Supplement no. 10, UN Doc. A/53/10.

Yearbook of the International Law Commission 1975, UN Doc. A/CN.4/SER.A/1975/ Add. 1.

ICJ, Case Concerning Application of the Convention on the Prevention and Punishment of the Crime of Genocide (Bosnia and Hercegovina v. Serbia and Montenegro), Judgement of 26 February 2007.

ICJ, Case Concerning Armed Activities on the Republic of the Congo (Democratic Republic of the Congo v. Uganda), Judgement of 19 December 2005.

ICJ, Case Concerning Military and Paramilitary Activities In and Against Nicaragua (Nicaragua v. United States of America), Judgement of 27 June 1986.

ICJ, Case Concerning United States Diplomatic and Consular Staff in Teheran (United States of America v. Iran), Judgement of 24 May 1980.

ICTY, Prosecutor v. Duško Tadic, Appeals Chamber Judgement of 15 July 1999, Case no. IT-94-1-A.

Iran-U.S. Claims Tribunal, Kenneth P. Yeager v. Islamic Republic of Iran, 1987. 


\section{SUMMARY}

\section{The International Legal Issue of Attributing Conduct to a State - The Case Law of the International Courts and Tribunals}

The article aims to broaden the subject of the attribution of conduct to a State by presenting different grounds for attributing State responsibility. It surveys main the principles of attribution, which were affirmed in international judicial decisions and specifies circumstances which extend beyond the general rule under which States incur responsibility only for the conduct of its organs. The provisions of the Articles on the Responsibility of States for Internationally Wrongful Acts constitute a primary point of reference of the research and are followed by examples of their practical application.

Keywords: responsibility of States, attribution of conduct, de facto State organs, effective control test, overall control test

Sylwia Stryjkowska, Adam Mickiewicz University Poznań, Faculty of Law and Administration, Al. Niepodległości 53, 61-714 Poznań, e-mail: sylwia.stryjkowska@amu.edu.pl. 
